\title{
Describing Family Needs within Adult Critical Care Units at a Military Hospital in Jeddah, Saudi Arabia
}

\author{
Jennifer de Beer $^{1} \&$ Hend Alnajjar ${ }^{1}$ \\ ${ }^{1}$ College of Nursing, King Saud bin Abdulaziz University for Health Sciences, Um Salem Street, Jeddah, \\ Kingdom of Saudi Arabia. \\ Correspondence: Jennifer de Beer, Assistant Professor, College of Nursing, King Saud bin Abdulaziz University \\ for Health Sciences, Um Salem Street, Jeddah, Kingdom of Saudi Arabia.
}

Received: October 22, 2017

Accepted: November 30, 2017

Online Published: December 14, 2017

doi:10.20849/ijsn.v2i2.246

URL: https://doi.org/10.20849/ijsn.v2i2.246

\begin{abstract}
Background: Family members have traumatic experiences when a loved one is admitted into critical care units as they are not psychological prepared for the sudden illness of a loved one. Attending to the needs of family members of critically ill patients is vital in providing appropriate holistic care for both the patient and the family.

Methods: A cross sectional descriptive quantitative research design was used. The study was conducted in a military hospital in Jeddah, Saudi Arabia, within 10 critical care units. A total of 25 doctors, 66 critical care nurses and 38 family members were included in the study. Data was collected using the Critical Care Family Needs Inventory (CCFNI), a Likert tool developed by Jane Leske which has established reliability of 0.80-0.97.

Findings: The most important need as perceived by doctors was "the "need to know the expected outcome' regarding the patient's condition, $M=3.72(S D=0.54)$, while critical care nurses' perceived the most important family need as "To have explanations of the environment before going into the critical care unit for the first time, $M=3.65(S D=0.54)$. Further to this, family members' perceived "To be assured that the best care possible is being given to the patient" as the most important family need $M=3.76(\mathrm{SD}=0.54)$.
\end{abstract}

Conclusion: Health care professionals have a responsibility towards meeting these needs in order to provide care that is holistic in nature that encompasses the basic tenets of patient-family centered care.

Keywords: critical illness, family members, family centered care, family needs during critical illness.

\section{Background}

Critical illness often occurs unplanned, resulting in family members feeling venerable and helpless with no indication of what to expect in terms of patient outcomes (Maxwell, Stuenkel \& Saylor, 2007). This unexpected admission of a loved one may result in negative effects on the everyday lives of family members as they have little time to adjust to the situation (de Beer \& Brysiewicz, 2016). Family members have traumatic experiences when a loved one is admitted into critical care units as they are not psychological prepared for the sudden illness of a loved one. This results in family members becoming disrupted and disorganized (Gundo, Bodole, Lengu \& Maluwa, 2014).

During a critical illness of a loved one, family members take on additional essential roles for patients who maybe unconscious or unable to communicate. Not only do family members provide vital support to the patient during this time but they also become the "voice" of the patient (de Beer \& Brysiewicz, 2017: 26). According to Bailey, Sabbagh, Loiselle, Boileau \& McVey (2010), family members are emotionally burdened by the overwhelming nature of the critical illness and if they have inadequate coping resources their supportive roles can be inhibited, thus preventing them from acting in the best interest of the patient.

Attending to the needs of family members of critically ill patients is vital in providing appropriate holistic care for both the patient and the family (Kynoch, Chang, Coyer \& McArdel, 2016). Family needs have been extensively researched; beginning in 1979 starting with Molter (1979) both quantitative and qualitative methods have been utilized to assess the needs of families which is evident throughout the literature. A plethora of studies and papers have been published on identifying and meeting the needs of families of critical care patients (de Beer \& Brysiwicz, 2016; Bailey et al., 2010; McAdam and Puntillo, 2009; Ågård and Harder, 2007; Takman and Severinsson, 2006; Auerbach, Kiesler, Wartella, Rausch, Ward \& Ivatury, 2005; Chartier and Coutu-Wakulczyk, 
1989; Daley, 1984).

Despite the above mentioned studies, Kynoch et al (2016), proposed more rigorous high quality research studies investigating the interventions to meet the needs of family members within a critical care context. These authors completed a systematic review on the effectiveness of interventions to meet family needs of critically ill patients in an adult intensive care unit and further proposed research that provides more robust data on family members' needs would better inform health professionals in their practice. It is within this backdrop that the current study was undertaken. Within the context of Saudi Arabia and particularly the Western Region of Jeddah, there is a dearth of literature on family members needs within the context of critical care. There is an increase in the need for critical care services within the Saudi Arabian context due to the increasing population age, longer survival of previously incurable diseases, and advanced surgical procedures requiring mandatory critical care admission (AlOmari, Abdelwahed \& Alansari, 2015). As a result of this, the current study aimed to explore this phenomenon and add to the limited body of knowledge within and Arab context.

\section{Aim of the Study}

The aim of the study was to describe doctors, nurses and family members' perception on family needs in adult critical care units at a military hospital in Jeddah.

\section{Method}

\subsection{Research Design}

This study used a cross sectional descriptive quantitative research design.

\subsection{Setting of the Study}

A 751 bedded military hospital in the western region of Jeddah was used. All adult critical care units within this hospital was included in the study. Currently there are ten critical care units within the facility with a total of 100 allocated beds. This hospital offers tertiary care to military personnel, their family members and staff.

\subsection{Participants and Sample Size}

A total of 25 doctors, 66 critical care nurses and 38 family members were included in the study. A convenient sampling method was chosen.

\subsection{Data Collection Tool and Process}

Data collection included using a questionnaire titled the Critical Care Family Needs Inventory (CCFNI) a tool developed by Leske (1991). The tool has established reliability of 0.80-0.97 (Chien, Chui, Lam \& Ip, 2005; Gundo et al, 2014). The tool consisted of 45 items forming five (5) categories: support (items 1 to 14), information (items 15 to 23), proximity or closeness (items 24 to 32), assurance (items 33 to 39) and comfort (items 40 to 45). The responses were noted on a 4-point Likert scale, and the scoring was coded as not important (1), slightly important (2), important (3) and very important (4).

The same tool was used for all categories of respondents. The English version of the tool was used for doctors and nurses and an Arabic version was used for family members. The original English version was translated into Arabic by a qualified English to Arabic translator. This tool was then given to two Arabic speaking faculty staff members to verify that the Arabic content of the tool did not deviate from the original English content.

Charge nurses within the critical care units were approached and informed about the purpose of the study. Charge nurses agreed to disseminate the questionnaires to critical care nurses that were on duty, on both the evening and day shifts. However this technique resulted in a poor response rate. It was at this point that the researchers decided to utilize research assistants. Two research assistants were employed and collected the data from all respondents. Critical care nurses were personally approached by the research assistants whilst they were on duty and family members were approached whilst in the waiting area so as not to impose on visitation times. The Chief Critical Care consultant was approached for assistance in collection of data from doctors as data collection within the critical care units were not possible during the working hours of doctors. As a result, the Chief Consultant allocated a registrar who assisted with data collection by handing out questionaries' to the doctors before and after work hours.

\section{Ethical Considerations}

Ethical approval was obtained from the Institutional Review Board (ethics number RJ16/009/J) at the hospital concerned. Thereafter, necessary permission was obtained from the hospital management. The researchers assured the respondents of their voluntary participation and protection from any harm should they decide to withdraw from the study at any time. Informed consent was obtained from the respondents who were told that 
filling and returning the questionnaire was considered consent to participate in the study. Confidentiality, privacy and anonymity were maintained by ensuring that no names were attached to any questionnaire. The completed questionnaires were then secured in a locked cupboard only accessible to the researchers and will be kept for a period of five years from the date of ethical approval.

\section{Findings}

\subsection{Demographic Characteristics of Respondents}

Table 1. Doctor's demographic data in ICU unit

\begin{tabular}{|c|c|c|}
\hline & \multicolumn{2}{|c|}{$\begin{array}{c}\text { Doctors } \\
(\mathrm{n}=25)\end{array}$} \\
\hline & No. & $\%$ \\
\hline \multicolumn{3}{|l|}{ Gender } \\
\hline Male & 20 & 80.0 \\
\hline Female & 5 & 20.0 \\
\hline \multicolumn{3}{|l|}{ Age } \\
\hline $20-29$ & 7 & 28.0 \\
\hline $30-39$ & 8 & 32.0 \\
\hline $40-49$ & 6 & 24.0 \\
\hline$\geq 50$ & 4 & 16.0 \\
\hline Min. - Max. & \multicolumn{2}{|c|}{$25.0-56.0$} \\
\hline Mean \pm SD & \multicolumn{2}{|c|}{$37.44 \pm 10.21$} \\
\hline \multicolumn{3}{|l|}{ Job title doctor } \\
\hline Consultant & 4 & 16.0 \\
\hline Registrar & 20 & 80.0 \\
\hline Intern & 0 & 0.0 \\
\hline Others specify & 1 & 4.0 \\
\hline \multicolumn{3}{|l|}{ Nationality doctor } \\
\hline Saudi & 12 & 48.0 \\
\hline Egypt & 7 & 28.0 \\
\hline Palestinian & 3 & 12.0 \\
\hline Sudan & 2 & 8.0 \\
\hline Pakistan & 1 & 4.0 \\
\hline Syria & 0 & 0.0 \\
\hline India & 0 & 0.0 \\
\hline \multicolumn{3}{|l|}{ Years of experience } \\
\hline $0-5$ years & 11 & 44.0 \\
\hline $6-10$ years & 4 & 16.0 \\
\hline $11-15$ years & 5 & 20.0 \\
\hline 16- 19 years & 1 & 4.0 \\
\hline 20 and more & 4 & 16.0 \\
\hline
\end{tabular}

A total of 25 doctors, 66 critical care nurses and 38 family members were involved in the study. Of the 25 doctors that participated, majority (48\%) were from Saudi Arabia. Further to this the majority of doctors $(80 \%)$ were registrars, with most of them having $0-5$ years of experience within the critical care context. The mean age amongst doctors were 37.44 years with most of them being male (80\%) (Table 1) 
Table 2. Nurse demographic data in ICU unit

\begin{tabular}{|c|c|c|}
\hline & \multicolumn{2}{|c|}{$\begin{array}{l}\text { Nurse } \\
(n=63)\end{array}$} \\
\hline & No. & $\%$ \\
\hline \multicolumn{3}{|l|}{ Gender } \\
\hline Male & 13 & 20.6 \\
\hline Female & 50 & 79.4 \\
\hline \multicolumn{3}{|l|}{ Age } \\
\hline $20-29$ & 22 & 34.9 \\
\hline $30-39$ & 26 & 41.3 \\
\hline $40-49$ & 13 & 20.6 \\
\hline$\geq 50$ & 2 & 3.2 \\
\hline Min. - Max. & \multicolumn{2}{|c|}{$23.0-52.0$} \\
\hline Mean \pm SD & \multicolumn{2}{|c|}{$33.87 \pm 7.65$} \\
\hline \multicolumn{3}{|c|}{ Qualification nurse } \\
\hline Diploma & 15 & 25.4 \\
\hline Bachelor & 42 & 71.2 \\
\hline Masters & 2 & 3.4 \\
\hline \multicolumn{3}{|l|}{ Nationality nurse } \\
\hline Saudi & 13 & 20.6 \\
\hline Philippine & 16 & 25.4 \\
\hline Malaysia & 20 & 31.7 \\
\hline South Africa & 7 & 11.1 \\
\hline Jordan & 1 & 1.6 \\
\hline Others & 6 & 9.5 \\
\hline \multicolumn{3}{|c|}{ Years of experience } \\
\hline $0-5$ years & 24 & 38.1 \\
\hline $6-10$ years & 19 & 30.2 \\
\hline $11-15$ years & 11 & 17.5 \\
\hline 16- 19 years & 7 & 11.1 \\
\hline 20 and more & 2 & 3.2 \\
\hline
\end{tabular}

Sixty six critical care nurses participated in the study. Most nurses were expatriates, with $31.7 \%$ of nurses being Malaysians, 25.4\% being Filipinos, 11.1\% South Africans, 1.6\% Jordanian with 9.5\% of critical care nurses not stating a nationality. $20.6 \%$ of critical care nurses included in the study was Saudis. The majority of critical care nurses $(71.2 \%)$ had a bachelor's degree in nursing with $38.1 \%$ of nurses having $0-5$ years of experience within the critical care context. The mean age of critical care nurses were 33.87 years with most of them being female $(79.4 \%)$ (Table 2). 
Table 3. Family members' demographic data in ICU unit

\begin{tabular}{|c|c|c|}
\hline & \multicolumn{2}{|c|}{$\begin{array}{l}\text { Family members } \\
\qquad(\mathrm{n}=38)\end{array}$} \\
\hline & No. & $\%$ \\
\hline \multicolumn{3}{|l|}{ Gender } \\
\hline Male & 23 & 60.5 \\
\hline Female & 15 & 39.5 \\
\hline \multicolumn{3}{|l|}{ Age } \\
\hline $20-29$ & 6 & 15.8 \\
\hline $30-39$ & 5 & 13.2 \\
\hline $40-49$ & 1 & 2.6 \\
\hline$\geq 50$ & 26 & 68.4 \\
\hline Min. - Max. & \multicolumn{2}{|c|}{$22.0-60.0$} \\
\hline Mean \pm SD. & \multicolumn{2}{|c|}{$44.95 \pm 11.67$} \\
\hline \multicolumn{3}{|c|}{ Nationality family members } \\
\hline Saudi & 38 & 100.0 \\
\hline Syrian & 0 & 0.0 \\
\hline \multicolumn{3}{|c|}{$\begin{array}{l}\text { The relationship with the admitted } \\
\text { patient }\end{array}$} \\
\hline Mother & 4 & 10.5 \\
\hline Father & 9 & 23.7 \\
\hline Son & 2 & 5.3 \\
\hline Daughter & 9 & 23.7 \\
\hline Others, specify & 14 & 36.8 \\
\hline \multicolumn{3}{|c|}{$\begin{array}{l}\text { First time to have family member in } \\
\text { ICU }\end{array}$} \\
\hline Yes & 26 & 68.4 \\
\hline No & 12 & 31.6 \\
\hline
\end{tabular}

A total of 38 family members participated in the study with all (100\%) of them being Saudi. Most family members were female $(60.5 \%)$ with $39.5 \%$ being male. The mean age of family members were 44.95 years. $68.4 \%$ of family members reported that this was the first time to have a loved one admitted to the critical care unit. $36.8 \%$ of family members visiting critical care during the study period were visiting the patient who was not part of their immediate family but rather from the extended family. However, $23.7 \%$ of family members were fathers of the patient admitted with $23.7 \%$ being daughters, $10.5 \%$ being mothers and $5.3 \%$ being sons (Table 3 ). 


\subsection{Family Needs}

\subsubsection{Most Important Family Needs}

Table 4. The 10 most important needs perceived

\begin{tabular}{|c|c|c|c|c|}
\hline & & & $\begin{array}{l}\text { Doctors } \\
(\mathrm{n}=25)\end{array}$ & Ranking \\
\hline & & Dimension & Mean \pm SD. & \\
\hline Q1 & To know the expected outcome & Assurance & $3.72 \pm 0.54$ & 1 \\
\hline Q5 & To have questions answered honestly & Assurance & $3.72 \pm 0.54$ & 1 \\
\hline Q11 & To know which staff members could give what type of information & Information & $3.64 \pm 0.49$ & 3 \\
\hline Q17 & To be assured that the best care possible is being given to the patient & Assurance & $3.60 \pm 0.58$ & 4 \\
\hline Q19 & To know exactly what is being done for the patient & Information & $3.52 \pm 0.59$ & 5 \\
\hline Q13 & To know why things were done for the patient & Information & $3.48 \pm 0.65$ & 6 \\
\hline Q35 & To have explanations given that are understandable & Assurance & $3.44 \pm 0.71$ & 7 \\
\hline Q21 & To feel accepted by the hospital staff & Comfort & $3.40 \pm 0.65$ & 8 \\
\hline Q9 & To have directions as to what to do at the bedside & Support & $3.36 \pm 0.64$ & 9 \\
\hline Q39 & To help with the patient's physical care & Assurance & $\begin{array}{c}3.36 \pm 0.70 \\
\text { Critical care Nurses } \\
\qquad(\mathrm{n}=66) \\
(\text { Mean } \pm \text { SD. }\end{array}$ & $\begin{array}{l}9 \\
\text { Ranking }\end{array}$ \\
\hline Q2 & $\begin{array}{l}\text { To have explanations of the environment before going into the critical } \\
\text { care unit for the first time }\end{array}$ & Assurance & $3.65 \pm 0.54$ & 1 \\
\hline Q1 & To know the expected outcome & Assurance & $3.60 \pm 0.64$ & 2 \\
\hline Q5 & To have questions answered honestly & Assurance & $3.59 \pm 0.59$ & 3 \\
\hline Q13 & To know why things were done for the patient & Information & $3.54 \pm 0.62$ & 4 \\
\hline Q17 & To be assured that the best care possible is being given to the patient & Assurance & $3.52 \pm 0.62$ & 5 \\
\hline Q16 & To know how the patient is being treated medically & Information & $3.51 \pm 0.56$ & 6 \\
\hline Q19 & To know exactly what is being done for the patient & Information & $3.49 \pm 0.59$ & 7 \\
\hline Q3 & To talk to the doctor every day & Assurance & $3.40 \pm 0.68$ & 8 \\
\hline Q9 & To have directions as to what to do at the bedside & Support & $3.35 \pm 0.68$ & 9 \\
\hline Q7 & To talk about feelings about what has happened & Comfort & $\begin{array}{l}3.33 \pm 0.70 \\
\text { Family members } \\
\quad(\mathrm{n}=38) \\
\text { Mean } \pm \text { SD. }\end{array}$ & $\begin{array}{c}10 \\
\text { Ranking }\end{array}$ \\
\hline Q17 & To be assured that the best care possible is being given to the patient & Assurance & $3.76 \pm 0.54$ & 1 \\
\hline Q43 & To know specific facts concerning the patient's progress & Assurance & $3.76 \pm 0.54$ & 1 \\
\hline Q3 & To talk to the doctor every day & Assurance & $3.74 \pm 0.55$ & 3 \\
\hline Q16 & To know how the patient is being treated medically & Information & $3.74 \pm 0.72$ & 3 \\
\hline Q27 & To have someone be concerned with patient's health & Support & $3.74 \pm 0.55$ & 3 \\
\hline Q13 & To know why things were done for the patient & Information & $3.71 \pm 0.65$ & 6 \\
\hline Q42 & To feel that the hospital personnel care about the patient & Assurance & $3.71 \pm 0.57$ & 6 \\
\hline Q1 & To know the expected outcome & Assurance & $3.68 \pm 0.57$ & 8 \\
\hline Q14 & To feel there is hope & Comfort & $3.68 \pm 0.62$ & 8 \\
\hline Q17 & To be assured that the best care possible is being given to the patient. & Assurance & $3.76 \pm 0.54$ & 8 \\
\hline
\end{tabular}

The most important need as perceived by doctors was the "need to know the expected outcome $M=3.72$ ( $S D=$ 0.54), while critical care nurses' perceived the most important family need as "To have explanations of the environment before going into the critical care unit for the first time $M=3.65(S D=0.54)$ ". Further to this family members' perceived "To be assured that the best care possible is being given to the patient" as the most important family need $M=3.76(S D=0.54)$.

Further to this, the most import need perceived by doctors, critical care nurses and family members regarding family needs in critical care are all related to the dimension of assurance. In addition, the majority of needs from 
the 10 most important needs as perceived by all respondents in this study are related to the dimension of assurance: perception of assurance needs by doctors $-50 \%$, critical care nurses perception of assurance needs $50 \%$ and family member's perception of assurance needs $(60 \%)$ (Table 4$)$

\subsubsection{Other Needs and Dimensions}

From the 10 most important perceived family needs, needs related to the dimension of information featured as the second most important need by all respondents. The most important information need perceived by doctors as family needs were the need "to know which staff members could give what type of information $M=3.64$ ( $S D=$ 0.49) [ranked as number 3 from the top 10 needs]. Critical care nurses perceived the need "To know why things were done for the patient" as the most important information need $M=3.54(S D=0.62)$ [ranked at 4 from the top 10 needs]. The most important informational need as perceived by family members was the need to "To know how the patient is being treated medically" $M=3.74(S D=0.72)$ [ranked at 3 from the top 10 needs] (Table 4)

The other perceived family needs were related to the dimension of comfort and support. Doctors perceived the need "to feel accepted by the hospital staff" $M=3.40(S D=0.65)$ [ranked at 8 from the top 10 needs] as the most important comfort need while critical care nurses perceived the need to" talk about feelings about what happened" $M=3.33(S D=0.70)$ [ranked at 10 from the top 10 needs] the most important comfort need. Finally for comfort needs, family members perceived "the need to feel hope" $M=3.68(S D=0.62)$ [ranked at 8 from the top 10 needs] as the most important comfort need. With regards to perceived needs related to the dimension of support, both doctors and critical care nurses ranked comfort needs less important than family members. Doctors and critical care nurses perceived the need "To have directions as to what to do at the bedside" $M=3.36$ ( $S D=$ 0.64 ) and $M=3.35$ ( $S D=0.68$ ) respectively both ranking at 9 from the top 10 needs) as the most important support need. However, family members' perception of support needs was ranked as the third highest need from the top 10 needs in comparison to doctors and critical care nurses. Interestingly there were no needs related to the dimension of proximity amongst the top 10 needs (Table 4 ).

\subsubsection{Least Important Needs and Its Related Dimensions}

Both doctors and critical care nurses ranked the need "to visit the patient at any time" as the last most important need perceived by doctors and critical care nurses. With regards to family members, the last perceived need was "To talk to the same nurse every day" $M=2.89(S D=1.0)$.

Table 5. Comparison between the three groups according to items of perception $(n=126)$ in ICU unit

\begin{tabular}{|c|c|c|c|c|c|c|c|c|}
\hline & \multicolumn{2}{|c|}{ Doctors $(n=25)$} & \multicolumn{2}{|c|}{ Nurses $(n=63)$} & \multicolumn{2}{|c|}{$\begin{array}{c}\text { Family members } \\
(\mathrm{n}=\mathbf{3 8})\end{array}$} & \multirow[t]{2}{*}{$\begin{array}{l}\text { Test of } \\
\text { sig. }\end{array}$} & \multirow[t]{2}{*}{$\mathbf{p}$} \\
\hline Overall & No. & $\%$ & No. & $\%$ & No. & $\%$ & & \\
\hline $\begin{array}{l}<33.3 \\
33.3-66.6 \\
>66.6 \%\end{array}$ & $\begin{array}{c}0 \\
9 \\
16\end{array}$ & $\begin{array}{c}0.0 \\
36.0 \\
64.0\end{array}$ & $\begin{array}{c}3 \\
26 \\
34\end{array}$ & $\begin{array}{c}4.8 \\
41.3 \\
54.0\end{array}$ & $\begin{array}{c}0 \\
7 \\
31\end{array}$ & $\begin{array}{c}0.0 \\
18.4 \\
81.6\end{array}$ & $\begin{array}{c}\chi^{2}=8.5 \\
23^{*}\end{array}$ & $\begin{array}{l}{ }_{\mathrm{p}}^{\mathrm{MC}}= \\
0.039^{*}\end{array}$ \\
\hline Overall & & & & & & & & \\
\hline $\begin{array}{l}<\mathbf{5 0} \% \\
\mathbf{5 0}-<\mathbf{7 5 \%} \\
\geq \mathbf{7 5 \%}\end{array}$ & $\begin{array}{c}3 \\
13 \\
9\end{array}$ & $\begin{array}{l}12.0 \\
52.0 \\
36.0\end{array}$ & $\begin{array}{c}9 \\
32 \\
22\end{array}$ & $\begin{array}{l}14.3 \\
50.8 \\
34.9\end{array}$ & $\begin{array}{c}0 \\
11 \\
27\end{array}$ & $\begin{array}{c}0.0 \\
28.9 \\
71.1\end{array}$ & $\begin{array}{c}\chi^{2}=16.1 \\
35^{*}\end{array}$ & $\begin{array}{l}{ }_{\mathrm{p}}^{\mathrm{MC}}= \\
0.002^{*}\end{array}$ \\
\hline $\begin{array}{l}\text { Total score } \\
\quad \text { Min. - Max. } \\
\text { Mean } \pm \text { SD. } \\
\% \text { score }\end{array}$ & \multicolumn{2}{|c|}{$\begin{array}{c}99.0-175.0 \\
135.64 \pm 18.43\end{array}$} & \multicolumn{2}{|c|}{$\begin{array}{c}80.0-171.0 \\
133.10 \pm 21.69\end{array}$} & \multicolumn{2}{|c|}{$\begin{array}{c}111.0-169.0 \\
146.26+14.41\end{array}$} & $\begin{array}{c}\mathrm{F}=5.77 \\
4^{*}\end{array}$ & $0.004^{*}$ \\
\hline $\begin{array}{l}\text { Min. - Max. } \\
\text { Mean } \pm \text { SD. }\end{array}$ & \multicolumn{2}{|c|}{$\begin{array}{l}41.67-99.24 \\
69.42 \pm 13.96\end{array}$} & \multicolumn{2}{|c|}{$\begin{array}{l}27.27-96.21 \\
67.50 \pm 16.43\end{array}$} & \multicolumn{2}{|c|}{$\begin{array}{l}50.76-94.70 \\
77.47 \pm 10.92\end{array}$} & $\begin{array}{c}\mathrm{F}=5.77 \\
4^{*}\end{array}$ & $0.004^{*}$ \\
\hline
\end{tabular}

F: $F$ value for ANOVA test

$\chi^{2}, p: \chi^{2}$ and $p$ values for Chi square test

MC: Monte Carlo for Chi square test

*: Statistically significant at $\mathrm{p} \leq 0.05$ 


\subsubsection{Proximity Needs}

In addition it is noted that the perceived family need ranked the lowest amongst doctors and critical care nurses is related to the dimension of proximity. There seems to be differences in the ranking between proximity needs amongst doctors and nurses as compared to family members. The table 4 highlights family member's perception of proximity needs were given more priority as opposed to doctors and critical care nurses. With regards to the last 10 needs as perceived by all respondents, $43 \%$ of proximity was ranked in the last 10 needs by doctors, $57 \%$ of proximity needs were ranked in the last 10 needs by nurses whilst only $29 \%$ of proximity needs were ranked in the last top 10 needs by family members

Table 6. Dimension of proximity

\begin{tabular}{|c|c|c|c|c|c|c|c|}
\hline & \multirow[t]{2}{*}{ Dimension of proximity } & \multicolumn{2}{|l|}{$\begin{array}{l}\text { Doctors } \\
(\mathbf{n}=\mathbf{2 3})\end{array}$} & \multirow[t]{2}{*}{ Nurse $(n=67)$} & \multirow[t]{2}{*}{ Rank } & $\begin{array}{l}\text { Family } \\
\text { members } \\
(n=11)\end{array}$ & \multirow[t]{2}{*}{$\begin{array}{l}\text { Ran } \\
\mathbf{k}\end{array}$} \\
\hline & & $\begin{array}{ll}\text { Mean } \quad \pm \\
\text { SD. }\end{array}$ & & & & $\begin{array}{ll}\text { Mean } \quad \pm \\
\text { SD. }\end{array}$ & \\
\hline Q8 & $\begin{array}{l}\text { To have good food available } \\
\text { in the hospital }\end{array}$ & $3.12 \pm 0.78$ & 21 & $3.21 \pm 0.94$ & 18 & $3.39 \pm 0.86$ & 23 \\
\hline Q10 & To visit at any time & $2.28 \pm 1.14$ & 45 & $1.95 \pm 0.97$ & 45 & $3.08 \pm 1.08$ & 34 \\
\hline Q23 & $\begin{array}{l}\text { To have a telephone near the } \\
\text { waiting room }\end{array}$ & $2.88 \pm 0.83$ & 32 & $2.81 \pm 0.95$ & 33 & $2.95 \pm 1.04$ & 38 \\
\hline Q29 & $\begin{array}{l}\text { To talk to the same nurse } \\
\text { every day }\end{array}$ & $2.56 \pm 1.04$ & 39 & $1.98 \pm 0.98$ & 44 & $2.89 \pm 1.09$ & 41 \\
\hline Q32 & $\begin{array}{l}\text { To have a bathroom near the } \\
\text { waiting room }\end{array}$ & $3.24 \pm 0.78$ & 17 & $2.94 \pm 0.88$ & 26 & $3.45 \pm 0.80$ & 22 \\
\hline Q44 & To see the patient frequently & $2.96 \pm 0.73$ & 28 & $2.76 \pm 1.01$ & 35 & $3.61 \pm 0.64$ & 14 \\
\hline Q45 & $\begin{array}{l}\text { To have the waiting room } \\
\text { near the patient }\end{array}$ & $2.52 \pm 0.92$ & 42 & $2.56 \pm 0.98$ & 41 & $3.47 \pm 0.73$ & 21 \\
\hline
\end{tabular}

\section{Discussion}

The findings of this study highlights that the most important needs were needs relating to assurance. These findings are reiterated by Dharmalingam, Kamaluddin, Hassan \& Zaini (2016) who also found that assurance needs were the most important family needs identified. Within the study by Dharmalingam et al (2016) the top six needs of family members were related to assurance needs. Assurance to know that the best possible care was given aids in developing confidence and trust amongst family members towards the care provided by health care professionals. This is highlighted in the seminal work by Leske (1991) who stated that assurance is an important family need as it reduces uncertainty, stress among family members and simultaneously gives hope of better outcome expectations. According to Chatzaki, Klimathianaki, Anastasaki, Chatzakis, Apostolakou \& Georgopoulous (2012), reassurance needs items were consistently singled out as most important regardless of the participant's background.

In addition, the findings of this study also revealed that information needs were important perceived needs of family members. The priority information needs focused on information regarding the medical care of the patient According to Zainah, Sasikala, Nurfarieeza \& Ho (2016) health care professionals should take great efforts in providing information to family members, which results in trust and effective communication between them and family members. This can prevent unnecessary misunderstandings between family members and health care professional and promotes confidence amongst family members that the best possible care was given to a loved one. In addition, Cypress (2011), reported that when family members are provided with information about the care of the patient in the unfamiliar context of critical care, their anxiety is reduced.

Within the present study, critical care nurses and doctors ranked proximity needs lower than the ranking of proximity needs by family members. Further to this, the most important proximal need of family members was to see the patient frequently. Traditionally within the critical care context, there are restrictions in visiting the 
patient. Al Mutair, Plummer, O' Brien \& Clerehan et al (2013), argued that restricted visitation practices in critical care in Saudi Arabia are based on tradition rather than evidence and the findings of their study revealed that family members prefer flexible visiting practices. Davidson, Powers, Hedyat, Tieszen, Kon et al (2007) expressed that restricted visiting hours decreases family member satisfaction as this prevents them from obtaining information regarding the patient. Further to proximity needs, Zainah, et al (2016) reported that proximity needs are influenced by the type of relationship between the patient and family members. These authors found within their study that spouses had greater proximal needs $(\mathrm{M}=3.60)$, than parents $(\mathrm{M}=3.50)$ and other relatives $(\mathrm{M}=3.38)$.

\section{Limitations}

This study included just one hospital in Jeddah. In addition the sample size was small which could affect the generalizability of the results. Further to this, family members omitted providing their ages on the questionnaire, which made correlations between demographics and family needs difficult.

\section{Recommendations}

Future research using space triangulation is needed to explore the phenomena including other areas within the Saudi context. In addition, using a qualitative approach to ascertain deeper understandings of the needs of family members is needed especially within this context where family orientation is a strong aspect of the Saudi culture.

\section{Conclusion}

This study highlighted that family needs are important to be assessed and met. Health care professionals have a responsibility towards meeting these needs in order to provide care that is holistic in nature that encompasses the basic tenets of patient-family centered care.

\section{References}

Ågård, A., \& Harder, I. (2007). Relatives' experiences in intensive care- finding a place in a world of uncertainty. Intensive and Critical Care Nursing, 23(3), 170-177. https://doi.org/10.1016/j.iccn.2006.11.008

Al-Omari, A., Abelwahed, HS., \& Alansar, MA. (2015). Critical care services in Saudi Arabia. Saudi Medical Journal, 36(6), 759-761. https://doi.org/10.15537/smj.2015.6.11204

Al-Mutair, AS, Plummer, V, O'Brien, A., \& Clerehan, R. (2013). Family needs and involvement in the intensive care unit: a literature review. J Clin Nurs, 22(13-14), 1805-1817. https://doi.org/10.1111/jocn.12065

Auerbach, SM., Kiesler, DJ., Wartella, J., Rausch, S., Ward, K R., \& Ivatury, R. (2005). Optimism, satisfaction with needs met, interpersonal perceptions of the healthcare team, and emotional distress in patients' family members during critical care hospitalization. American Journal of Critical Care, 14(3), 202-210.

Bailey, J., Sabbagh, M., Loiselle, C., Boileau, J., \& McVey, I. (2010). Supporting families, in the ICU: a descriptive correlation study of informational support, anxiety, and satisfaction with care. Intensive and Critical Care Nursing, 26(2), 114-122. https://doi.org/10.1016/j.iccn.2009.12.006

Chartier, 1., \& Coutu-wakulczyk, G. (1989). Families in ICU: their needs and anxiety level. Intensive care Nursing, 5(1), 11-18. https://doi.org/10.1016/0266-612X(89)90035-7

Chatzaki, M., Klimathianaki, M., Anastasaki, M., Chatzakis, G., Apostolakou, E., \& Georgopoulos, D. (2012). Defining the needs of ICU patients in a suburban/rural Greek population, a prospective cohort study. J Clin Nurs, 21(13-14), 1831-1839. https://doi.org/10.1111/j.1365-2702.2011.04022.x

Chien, WT., Chiu, YL., Lam, LW, \& Ip, WY. (2006). Effects of a needs-based education programme for family carers with a relative in an intensive care unit: A quasi-experimental study. Int J Nurs Stud. 2006, 43(1), 39-50. https://doi.org/10.1016/j.jinurstu.2005.01.006

Cypress, BS. (2011). The lived ICU experiences of nurses, patients and family members: A phenomenological study with Merleau-Pontian perspective. Intensive and Critical Care Nursing, 27(5), 273-280. https://doi.org/10.1016/j.iccn.2011.08.001

Daley, L. (1984). The perceived immediate needs of families with relatives in the intensive care setting. Heart and Lung, 13(3), 231- 237.

Davidson, J., Powers, K., Hedayat, K., Tieszen, M., Kon, A., ... Shepard, E. (2007). Clinical practice guidelines for support of the family in the patient-centred intensive care unit: American college of critical care medicine task force 2004-2005. Critical Care Medicine, 35, 605-622. https://doi.org/10.1097/01.CCM.0000254067.14607.EB 
De Beer, J., \& Byrsiewicz, P. (2017). The conceptualisation of family care during critical illness in KwaZulu-Natal, South Africa. Health Sa Gesonheid, 22(2017), $20-27$. https://doi.org/10.1016/j.hsag.2016.01.006

De Beer, J., \& Brysiewicz, P. (2016). The needs of family members of intensive care unit patients: a grounded theory study. SAJCC, 32(2), 44-49. https://doi.org/10.7196/SAJCC.2016.v32i2.298

Dharmalingam, TK., Kamaluddin, MR., Hassan, SK., \& Zaini, HRM. (2016). The needs of Malaysian family members of critical ill patients treated in intensive care unit, Hospital Universiti Sains Malaysia. Malaysian Journal of Medicine and Health Sciences, 12(2), 8-15.

Gundo, R., Bodole, F., Lengu, E., \& Maluwa, A. (2014). Comparison of nurse's and families' perception of family needs in critical care unit at referral hospital in Malawi. Open $J$ Nurs, 4(4), 312-320. https://doi.org/10.4236/ojn.2014.44036

Kynoch, K., Chang, A., Coyer, F., \& McArdel, A. (2014). The effectiveness of interventions to meet family needs of critically ill patients in an adult intensive care unit: a systematic review protocol update. The JBI Database of Systematic Reviews and Implementation Reports, 12(10), 1-10. https://doi.org/10.11124/jbisrir-2014-1881

Leske, JS. (1991). Internal psychometric properties of the Critical Care Family Needs Inventory. Heart Lung, 20(3), 236-244.

Molter, N. (1979). Needs of relatives of critically ill patients. A descriptive study. Heart and Lung. Journal of Acute Critical Care, 8(2), 329-334.

Zainah, M., Sasikal, M., Nurfariezza, MA., \& HO, SE. (2016). Needs of family members of critically ill patients in a critical care unit at university, Kebangsaan, Malaysia Medical Center. Medical \& Health, 11(1), 11-21.

\section{Copyrights}

Copyright for this article is retained by the author(s), with first publication rights granted to the journal.

This is an open-access article distributed under the terms and conditions of the Creative Commons Attribution license (http://creativecommons.org/licenses/by/4.0/). 